9. Міграція з окупованих територій: куди прямують переселенці [Електронний ресурс] // Слово і діло. Головний сайт про політиків. - Режим доступу: https://www.slovoidilo.ua/2017/02/13/infografika/suspilstvo/ mihracziya-z-okupovanyx-terytorij-kudy-pryamuyut-pereselenczi

10. Про кількість та склад населення Украӥни за підсумками Всеукраӥнського перепису населення 2001 року [Електронний ресурс]. - Режим доступу : http://2001.ukrcensus.gov.ua/results/general/city/

11. Проскурніна А. А. Статистичний аналіз чисельності та структури населення крайни [Електронний ресурс] / А. А. Проскурніна // Управління розвитком. - 2014. - № 11. - C.153-156. - Режсим доступу: http:// nbuv.gov.ua/UJRN/Uproz_2014_11_56

12. Статистичний щорічник Луганської області за 2009 рік / За ред. С. Г. Пілієва; Головне управління статистики у Луганській області. - Луганськ, 2010. - 514 c.

13. Статистичний щуорічник Луганської області за 2013 рік / За ред. І. В. Шаблієнко; Головне управління статистики у Луганській області. - Луганськ, 2014. - 479 с.

14. Статистичний щзорічник Луганської області за 2015 рік / За ред. Д. Я. Протопопова; Головне управління статистики у Луганській області. - Сєвєродонецьк, 2016. - 428 с.

15. Чисельність наявного населення Украӥни на 1 січня 2016 року [Електронний ресурс] / Відп. за випуск М. Б. Тімоніна. - К. : Державна служба статистики Украӥни. - 86 . - Режим доступу: httр:// www.ukrstat.gov.ual

16. Rowland R. H. Declining and Stagnant Towns of the USSR / R. H. Rowland // Soviet Geography: Rev. and Translation. - 1980. - № 21. - P. 195-218.

UDC 911.375:314.8

N. V. Husieva, PhD (Geography),

G. O. Kucheriava, PhD (Geography), Assistant Professor,

O. S. Suptelo, PhD student,

V. N. Karazin Kharkiv National University

\title{
CONCEPT OF WORLD CITIES: HUMAN-GEOGRAPHICAL APPROACH
}

Н. В. Гусєва, Г. О. Кучерява, О. С. Суптело. СТАНОВЛЕННЯ КОНЦЕПЦЇ̈ СВІТОВИХ МІСТ: СУСПІЛЬНОГЕОГРАФІЧНІ АСПЕКТИ. В статті проведено дослідження еволючії конщепиії світових міст, виявлено суспільногеографічні аспекти ї̈ формування і розвитку. Світові (глобальні) міста викликають значну зацікавленість та є об'єктом дослідження спеціалістів різних сфер. В сучасній науковій літературі зустрічається иілий ряд термінів, щзо описують феномен світових міст, зокрема «глобальне місто», «світовий центр», «світовий фінансовий центрр, «космополіс», «інформаційне місто», «медійне місто», «метрополіс», «екуменополіс», «глобальний міський регіон», «столиия капіталу», «міжнародне місто», «місто, щя глобалізується», «мегамісто», «інтерактивне місто» тощьо. Дефініиії поняття «світові міста» спираються на такі аспекти як економічний розвиток, політичний вплив, сочіальна значимість. Можна виділити декілька підходів в ідентифікаиії феномена світового міста, заснованих на різних принципах, - геоекономічний, геополітичний, соиіокультурний, історико-географічний, геодемографічний, інформаційно-комунікаційний, сервісний, інноваційний. Важливим виглядає суспільно-географічний підхід, який поєднує всіх вищеперераховані та забезпечує максимально комплексне дослідження феномену світових міст.

Ключові слова: глобальне місто, світове місто, світовий цеентр, світовий фінансовий центр, космополіс, інформаційне місто, медійне місто, метрополіс, екуменополіс, глобальний міський регіон, столиия капіталу, міжнародне місто, місто, щзо глобалізується, мегамісто, інтерактивне місто, концепція світових міст, суспільно-географічний підхід до конщепиії світових міст.

Н. В. Гусева, А. А. Кучерявая, О. С. Суптело. СТАНОВЛЕНИЕ КОНЦЕПЦИИ МИРОВЫХ ГОРОДОВ: ОБЩЕСТВЕННО-ГЕОГРАФИЧЕСКИЕ АСПЕКТЫ. В статье проведено исследование эволюџии конџепџии мировых городов, выявлено общественно-географические аспекты ее формирования и развития. Мировые (глобальные) города вызывают большой интерес и являются объектом исследования специилистов разных сфер. В современной научной литературе встречается иельй ряд терминов, описываюших феномен мировых городов, в частности «глобальный город», «мировой центр», «мировой финансовый центр», «космополис», «информаџионный город», «медийный город», «метрополис», «экуменополис», «глобальный городской регион», «столища капитала», «международный город», «глобализирующиийся город», «мегагород», «интерактивный город» и другие. Дефиниции понятия «мировой город» базируются на таких аспектах как экономическое развитие, политическое влияние, сочиальная значимость. Можно выделить несколько подходов в идентификации феномена мирового города, основанных на различных принципах, - геоэкономический, геополитический, соииокультурный, историкогеографический, геодемографический, информационно-коммуникационный, сервисный, инновачионный. Важным является общественно-географический подход, который объединяет всех вымеперечисленные и обеспечивает максимально комплексное исследование феномена мировых городов.

Ключевые слова: глобальный город, мировой город, мировой центр, мировой финансовый центр, космополис, информационный город, медийный город, метрополис, экуменополис, глобальный городской регион, столица капитала, международный город, глобализируюшийся город, мегагород, интерактивный город, конщепция мировых городов, общественногеографический подход к концепщии мировых городов.

Formulation of the problem. The modern stage of society's development can rightly be called the time of large cities: agglomerations, conurbations, megalopolises, alpha cities, megacities, metropolises, world (global) cities, etc., that have become the main players on the map of great politics, 
business, culture, science [9]. According to the forecasts of the McKinsey Global Institute, in the period from 2000 to 2025, about one third of the world's economic growth rates will be in the largest cities. GDP of 600 metropolises of the world in the period of 2010-2025 will increase by 30 trillion dollars. According to experts, in the XXI century, a dominant position will be occupied not by countries, but by cities that will shape the world order of the future, attracting capital and talents from around the world [4].

The phenomenon of large cities, which are of global significance and clearly distinguished by their world political potential, role, functions in the background of other cities, is of considerable interest and is the subject of research for specialists from different spheres. Historical epochs and formations have changed, the territorial organization and the priorities of the economic development have transformed, but large cities always remained at the forefront of progress, and the interest in them never faded away. Recently, among all the diversity of types of large cities, the increased attention of the broad scientific circles is attracted to the formation of their special category - world or global cities [15]. The study of world cities at the present stage of society's development is complicated by a number of aspects, including:

- complex and dynamic development of geopolitical and geoeconomic world space, which are the reasons for the rapid transformation of cities;

- complexity of a statistical base formation for the study of world cities, which is expressed in a large amount of diverse information and limited access to it;

- lack of a holistic and unique methodology for studying world cities.

Analysis of previous research. The founder of the modern trend in the study of world cities is P. Geddes, the urbanist from Britain («Cities in Evolution», 1915), who introduced the category of "world city» for the first time into the scientific circle [27]. The author of the concept of «global city» is the professor of sociology at the University of Chicago S. Sassen («Global city: New-York, London, Tokyo», 1991) [31]. At one time, studies of world cities were carried out by C. Abbott, J. Allen, J. Beaverstock, F. Braudel, G. Wolff, P. Geddes, N. Glickman, B. Derudder, C. Doxiadis, E. Isin, Y. Cassis, M. Castells, R. Van Kempen, D. Clark, R. Kohen, L. Mumford, P. Marcuse, P. Knox, P. Alderson, H. Reed， S. Sassen， A. Scott， R. Smith， N. Thrift, D. Walker, R. Florida, J. Freidman, A. E. Tschoegl, S. Hymer, M. Hoyler, P. Hall, Y. Jao and other. To date, large-scale and solid research of world cities is conducted by P. Taylor and the group "Globalization and World Cities“(GaWC).
The results of studies on various aspects of the development of world cities are widely covered in the scientific works of Ukrainian and Russian scholars, in particular, O. V. Boyko-Boychuk, G. V. Chernova, E. G. Dovbish, O. L. Dronova, S. I. Ishchuk, O. V. Gladkey, Yu. V. Kasyanchuk, N. S. Nimchenko， L. G. Rudenko, D. A. Savkin, I. G Savchuk, E. N. Samburova, I. V. Skavrovska， N. A. Sluka， I. M. Voronin， I. G. Zhivotovska and other scientists.

The purpose of the work is to study the human-geographical approach to the formation and development of the concept of world (global) cities in the XX-XXI centuries.

Results. At the beginning of the concept formation of world cities, this category was used to designate cities of special cultural and religious significance such as Rome or Paris, as well as for the capitals of former empires such as London, Paris, Vienna, Madrid [31]. Modern theory of world cities is primarily due to their particular participation in global socio-political processes and the world economy. Such centers are distinguished not by population or by the status of the capitals of the largest countries, but by the range of actions and the degree of political influence and economic power. They are a kind of command and control centers of the global economic system, occupying a dominant position in the city's hierarchy of the planet [23]

Use of a wide range of methods and means of studying world cities contributed to the emergence of a number of terms describing this phenomenon, in particular, including «world city», "global city», «world center», «world financial center», «cosmopolis», «information city», «media city», «metropolis», «ecumenopolis», «global city region», «capitals of capital», «international city», «globalizing city», «megacity», «interactive city», etc. (tabl. 1). The variety of terms is an indicator that reflects the ambiguity and complexity of this phenomenon in modern science, as well as the diversity of approaches in its study.

In modern scientific literature it is proposed to consider the world city not as a concrete term, but as a theoretical concept - universals, which implies a special role of the city in the development of human civilization. From these positions, the world city stands, firstly, as a phenomenon unique and singular; secondly, the scope of its influence clearly has a planetary or, ultimately, macro-regional coverage; thirdly, the world city represents a special force concentrator, whether in the field of ideology, religion, military force, innovation economy, etc.; fourthly, it acts as a hegemon, functions as a governing and controlling element within the framework of another, «subordinate» territorial-social system; fifthly, the spatial organization of such a system has a clearly pronounced center-peripheral character; sixthly, the 
Evolution of the concept of world (global) cities (compiled by the authors)

\begin{tabular}{|c|c|c|}
\hline Author (Source) & Definition of the concept & Examples of world cities \\
\hline $\begin{array}{l}\text { P. Geddes } \\
\text { «Cities in Evo- } \\
\text { lution», } 1915\end{array}$ & $\begin{array}{l}\text { World center - a city that plays a special role in world } \\
\text { development [27] }\end{array}$ & $\begin{array}{l}\text { The capitals of the leading } \\
\text { European countries - Lon- } \\
\text { don, Paris, Berlin, Vienna, } \\
\text { as well as a number of ma- } \\
\text { jor cities in the United } \\
\text { States - New York, Boston, } \\
\text { Chicago, Philadelphia }\end{array}$ \\
\hline $\begin{array}{l}\text { P. Hall } \\
\text { «The World Cit- } \\
\text { ies», 1966; } 1984\end{array}$ & $\begin{array}{l}\text { World city - a big city with an overproportional share of } \\
\text { world politics, economy, culture and art; centers of the } \\
\text { world with a high level of development in such areas as } \\
\text { trade, finance, education, culture and technology; a rel- } \\
\text { atively limited number of places where a significant part } \\
\text { of the world's most important affairs takes place. They are } \\
\text { the centers of, firstly, political power of the national and } \\
\text { world level, as well as the location of government and } \\
\text { various public organizations, trade unions, business fed- } \\
\text { erations, trade unions, etc.; secondly, national and int- } \\
\text { ernational trade and communications systems; thirdly, } \\
\text { banking, financial and insurance services; fourthly, pow- } \\
\text { erful transport streams and communications. Such cities } \\
\text { quickly turn into centers of concentration of all kinds of } \\
\text { activities, centers for collecting and disseminating inf- } \\
\text { ormation, art, culture and entertainment, the largest cen- } \\
\text { ters of consumption [28] }\end{array}$ & $\begin{array}{l}\text { London, Paris, Moscow, } \\
\text { New York, Tokyo and such } \\
\text { large urban areas as the } \\
\text { Randstad and the Rhine- } \\
\text { Ruhr }\end{array}$ \\
\hline $\begin{array}{c}\text { C. Doxiadis } \\
\text { «Ecumenopolis: } \\
\text { Tomorrow's } \\
\text { City», } 1968 \\
\end{array}$ & $\begin{array}{l}\text { Ecumenopolis - superglomeration or global agg- } \\
\text { lomeration, forming a solid network of resettlement on } \\
\text { the Earth's surface [24] }\end{array}$ & $\begin{array}{l}\text { At the time of the int- } \\
\text { roduction of the notion of } \\
\text { the cities that he met, did } \\
\text { not exist }\end{array}$ \\
\hline $\begin{array}{c}\text { H. Reed } \\
\text { «The Preemi- } \\
\text { nence of Interna- } \\
\text { tional Financial } \\
\text { Centers», 1981; } \\
\text { «Financial center } \\
\text { hegemony, int- } \\
\text { erest rates, and } \\
\text { the global pol- } \\
\text { itical economy», } \\
1989\end{array}$ & $\begin{array}{l}\text { Capitals of capital-cities as international or sup- } \\
\text { ranational financial centers. The emergence of financial } \\
\text { centers is due to the need to transform financial capital } \\
\text { from savings in investment. Financial centers exist bec- } \\
\text { ause of their ability to maintain a balance between sav- } \\
\text { ings and investments, and to act as an intermediary bet- } \\
\text { ween investors and borrowers [30] }\end{array}$ & $\begin{array}{l}\text { Global Centers: London, } \\
\text { New York (first order); } \\
\text { Amsterdam, Frankfurt am } \\
\text { Main, Paris, Tokyo, Zurich } \\
\text { (second order). } \\
\text { International financial cen- } \\
\text { ters: Basel, Bombay, Bru- } \\
\text { ssels, Vienna, Hamburg, } \\
\text { Hong Kong, Dusseldorf, } \\
\text { Madrid, Melbourne, Mex- } \\
\text { ico City, Rome, Rio de } \\
\text { Janeiro, San Paulo, San } \\
\text { Francisco, Sydney, Sin- } \\
\text { gapore, Toronto, Chicago } \\
\text { (first order ); Bahrain, } \\
\text { Buenos Aires, Kobe, Los } \\
\text { Angeles, Luxembourg, } \\
\text { Milan, Montreal, Osaka, } \\
\text { Panama, Seoul, Taipei } \\
\text { (second order) }\end{array}$ \\
\hline $\begin{array}{c}\text { F. Braudel } \\
\text { «Civilization and } \\
\text { Capitalism, 15th- } \\
\text { 18th Century», } \\
1984\end{array}$ & $\begin{array}{l}\text { Metropolises are big cities that perform international eco- } \\
\text { nomic functions. They take part in a constant flow of inf- } \\
\text { ormation, goods, capital, people, etc. [15] }\end{array}$ & $\begin{array}{l}\text { The overwhelming maj- } \\
\text { ority of capitals of the dev- } \\
\text { eloped countries of the } \\
\text { world }\end{array}$ \\
\hline
\end{tabular}




\begin{tabular}{|c|c|c|}
\hline $\begin{array}{l}\text { J. Friedmann, } \\
\text { G. Wolff } \\
\text { «World City for- } \\
\text { mation: An Age- } \\
\text { nda for Research } \\
\text { and Action», } \\
\text { 1982; } \\
\text { J. Friedmann } \\
\text { «The World City } \\
\text { Hypothesis», } \\
\text { 1986; } \\
\text { J. Friedmann } \\
\text { «Where we stand: } \\
\text { A decade of } \\
\text { world city re- } \\
\text { search», 1995 }\end{array}$ & $\begin{array}{l}\text { World cities - centers with obvious domination in the } \\
\text { economy, first of all, the financial sector and the service } \\
\text { sector. They are closely linked to the system of com- } \\
\text { munications and financial transactions and together form } \\
\text { a global system for controlling market expansion. These } \\
\text { cities act as intermediaries, offering national counterparts } \\
\text { access to global markets. A true global city should be dis- } \\
\text { tinguished by a number of features, among which: the } \\
\text { presence of relatively large population; the city should be } \\
\text { the place of concentration of the headquarters of the lar- } \\
\text { gest TNCs and international economic and geopolitical } \\
\text { organizations; be the world's financial center, an imp- } \\
\text { ortant global manufacturing center, a major transport and } \\
\text { communications hub of international importance, as well } \\
\text { as a highly developed area of the business services. The } \\
\text { position of the hypothesis of a world city: 1) the form and } \\
\text { degree of integration of world cities into the world eco- } \\
\text { nomy, their functions are crucial for any changes in the } \\
\text { internal urban structures; } 2 \text { ) used by global capital as the } \\
\text { «main units» of spatial organization of production and } \\
\text { sales; 3) the functions of control and management of the } \\
\text { world economy in them reflected in the structure and } \\
\text { dynamics of the urban economy, employment of the pop- } \\
\text { ulation; } 4 \text { ) serve as the main centers of concentration and } \\
\text { accumulation of international capital; 5) attract a large } \\
\text { number of migrants; } 6 \text { ) act as carriers of the main con- } \\
\text { tradictions of industrial capitalism, including the social } \\
\text { and spatial polarization of the population; } 7 \text { ) their growth } \\
\text { leads to an increase in social spending at rates exceeding } \\
\text { the fiscal capacity of the state [25] }\end{array}$ & $\begin{array}{l}\text { In the developed countries } \\
\text { (countries of the Center): } \\
\text { London, Paris, Rotterdam, } \\
\text { Frankfurt am Main, Zurich, } \\
\text { New York, Chicago, Los } \\
\text { Angeles, Tokyo (primary } \\
\text { centers); Brussels, Milan, } \\
\text { Vienna, Madrid, Toronto, } \\
\text { Miami, Houston, San Fra- } \\
\text { ncisco, Sydney (secondary } \\
\text { centers). In developing } \\
\text { countries (Semi-peripheral } \\
\text { countries): Sao Paulo, Sin- } \\
\text { gapore (primary centers); } \\
\text { Johannesburg, Buenos Air- } \\
\text { es, Rio de Janeiro, Caracas, } \\
\text { Mexico, Hong Kong, Tai- } \\
\text { pei, Manila, Bangkok, } \\
\text { Seoul (secondary centers) }\end{array}$ \\
\hline $\begin{array}{l}\text { Population Divi- } \\
\text { sion of the De- } \\
\text { partment of Eco- } \\
\text { nomic and Social } \\
\text { Affairs of the } \\
\text { United Nations } \\
\text { «The World's Cit- } \\
\text { ies » (published } \\
\text { since 1988) }\end{array}$ & $\begin{array}{l}\text { Megacities - cities with a population of more than } \\
10 \text { million people. }\end{array}$ & $\begin{array}{l}\text { In the world there were } \\
31 \text { megacities in } 2016 \\
\text { (Tokyo, Delhi, Shanghai, } \\
\text { Mumbai, São Paulo, Bei- } \\
\text { jing, Mexico City, Osaka, } \\
\text { Cairo, New York-Newark, } \\
\text { Dhaka, Karachi, Buenos } \\
\text { Aires, Kolkata, Istanbul, } \\
\text { Chongqing, Lagos, Manila, } \\
\text { Guangzhou, Rio de Jan- } \\
\text { eiro, Los Angeles-Long } \\
\text { Beach-Santa Ana, Mos- } \\
\text { cow, Kinshasa, Tianjin, } \\
\text { Paris, Shenzhen, Jakarta, } \\
\text { Bangalore, London, Che- } \\
\text { nnai, Lima) }\end{array}$ \\
\hline $\begin{array}{c}\text { N. Thrift } \\
\text { «The Geography } \\
\text { of International } \\
\text { Economic Dis- } \\
\text { order», } 1989\end{array}$ & $\begin{array}{l}\text { International (world) financial centers - global cities } \\
\text { based on the headquarters of international banks, exc- } \\
\text { hanges and transnational companies [32] }\end{array}$ & $\begin{array}{l}\text { Global Centers: New York, } \\
\text { London, Tokyo. Zonal cen- } \\
\text { ters: Paris, Singapore, } \\
\text { Hong Kong, Los Angeles. } \\
\text { Regional Centers: Sydney, } \\
\text { Chicago, Dallas, Miami, } \\
\text { Honolulu, San Francisco } \\
\end{array}$ \\
\hline $\begin{array}{l}\text { S. Sassen } \\
\text { «The Global Cit- } \\
\text { y: New York, } \\
\text { London, Tokyo», }\end{array}$ & $\begin{array}{l}\text { Global cities are postindustrial centers occupying a str- } \\
\text { ategic position in the global economy through the con- } \\
\text { centration of management and control functions, as well } \\
\text { as specialized in the field of professional business ser- }\end{array}$ & $\begin{array}{l}\text { New York, London and } \\
\text { Tokyo }\end{array}$ \\
\hline
\end{tabular}


1991; 2001;

«Cities in a Wor-

ld Economy», $1994 \$$

Sassen S.

«The Global

City: Introducing

a Concept», 2005

M. Castells

«The Inf-

ormational City:

Information Tec-

hnology, Eco-

nomic Res-

tructuring, and

the Urban Reg-

ional Process», 1989;

«The Rise of the

Network Society:

The Information

Age. Economy,

Society, and Culture», 1996

\section{Abbott}

«The International City Hypothesis: An Approach to the

Recent History of

U.S. Cities», 1997

Y. Jao

«Hong Kong as an International

Financial Centre, Evolution, Prospects and Policies», 1997; vices, which are represented by major financial ins-

titutions, consulting and audit companies, bar ass-

ociations, advertising agencies, etc.; cities with the most

internationalized economy and social structure; cities that are maximally integrated into the world economy and are largely drawing resources and development opportunities through or as a result of interaction in global urban networks. In the center of this interaction is the capital that freely moves the world and generates revenue. It distinguishes four key groups of high-tech services in the global cities: financial and business services, management and control, creative activities, tourism. The sphere of high-tech branches (high-tech) is developing dynamically, and in it production services (sector FIRE - finance, insurance, real estate). Thus, global cities are centers of: concentration of efforts to manage the organization of the world economy;

the concentration of finance and specialized companies that actualized the development of the manufacturing industry and transformed it into one of the leading sectors of the economy;

production, including creation of innovations in the leading branches of the economy;

market trade in goods, services and innovations [31]

Informational cities - great economic and financial centers as key elements of the global flow of information, innovation, capital, people, goods and symbols. The determinative feature of such cities is the concentration of administrative, managerial and production functions on a global scale. Cities form informational-power nodes, in which the most important decisions are made, transmitted to global economic networks. The new feature of the global city is its informational component: global cities play a crucial role in the development of the information society, creating the necessary network of decision-making variations at the highest level in different fields, significantly different from other cities on a global scale. Thus, the functions and capabilities of such a city go beyond the geographical scope, gaining a certain degree of independence from the political leadership of the country. The city is becoming a leader in the world political system along with the states [22]

International city - very widely differentiated concept, in which the role of the city is not reduced to the implementation of economic functions. Cities must have a wide range of economic, political and social characteristics [15]

International financial centre (IFC) - a global city that, along with administrative, commercial, cultural, implements the function of financial intermediation and becomes an important platform for the global financial system for attracting and redistributing capital from around the world. Representative offices of transnational banks, stock exchanges, auditor and consulting companies, and
The overwhelming majority of capitals of the developed countries of the world

The overwhelming majority of capitals of developed countries of the world

London, New York, Singapore, Hong Kong, Tokyo and others. The Global Financial Centers Index (GFCI) included 87 financial centers in 2016 that play an important 


\begin{tabular}{|c|c|c|}
\hline $\begin{array}{c}\text { A. E. Tschoegl } \\
\text { «International } \\
\text { Banking Centers, } \\
\text { Geography, and } \\
\text { Foreign Banks», } \\
\text { 2000; } \\
\text { Y. Cassis } \\
\text { «Capitals of Cap- } \\
\text { ital: The Rise and } \\
\text { Fall of Int- } \\
\text { ernational Fin- } \\
\text { ancial Centres } \\
\text { 1780-2009», } \\
2010\end{array}$ & $\begin{array}{l}\text { state regulators play an important role for the IFC. IFC } \\
\text { provides interaction between financial market par- } \\
\text { ticipants; the functioning of credit-financial and auditing } \\
\text { and consulting organizations [4]. IFC is an important uni- } \\
\text { fying element of global financial architecture, which is a } \\
\text { collection of financial institutions, markets, organizations } \\
\text { and professional communities [21]. In this regard, fin- } \\
\text { ancial centers become places where simultaneous ope- } \\
\text { rations can be carried out on the accumulation, transfer, } \\
\text { payment and exchange of financial capital or currency } \\
\text { [33]. IFC - centers of concentration of banks and spe- } \\
\text { cialized financial and credit institutes [29] }\end{array}$ & $\begin{array}{l}\text { role in the world financial } \\
\text { system }\end{array}$ \\
\hline $\begin{array}{l}\text { P. Taylor and } \\
\text { Globalization and } \\
\text { World Cities } \\
\text { (GaWC), Uni- } \\
\text { versity of Lou- } \\
\text { ghborough, UK } \\
\text { (a complex of } \\
\text { scientific works, } \\
\text { from the mid- } \\
\text { 1990s to this } \\
\text { time) }\end{array}$ & $\begin{array}{l}\text { World (global) cities - cities are closely interconnected } \\
\text { centers of corporate services that take advantage of their } \\
\text { geographical location and economic opportunities. The } \\
\text { world city not only provides access to world markets, but } \\
\text { also positively affects the quality of life and work of cit- } \\
\text { izens }[19 ; 35]\end{array}$ & $\begin{array}{l}\text { Leading global cities for } \\
\text { P. Taylor: London, New } \\
\text { York, Paris, Tokyo, Los } \\
\text { Angeles, Milan, Singapore, } \\
\text { Hong Kong, Chicago, Fra- } \\
\text { nkfurt am Main. Top 10 } \\
\text { Global Cities GaWC Ran- } \\
\text { kings: London, New York, } \\
\text { Singapore, Hong Kong, } \\
\text { Paris, Beijing, Tokyo, } \\
\text { Dubai, Shanghai, Sydney. } \\
\text { In total, the rating includes } \\
\text { about } 230 \text { cities }\end{array}$ \\
\hline $\begin{array}{c}\text { D. Clark } \\
\text { «Urban world, } \\
\text { global city», } \\
\text { 1996; } \\
\text { «Urban Wor- } \\
\text { ld/Global City», } \\
2003 \\
\end{array}$ & $\begin{array}{l}\text { Global cities become command and control centers of the } \\
\text { global economic system, with the focus of key ind- } \\
\text { ividuals, institutions and organizations that manage, man- } \\
\text { ipulate, dictate and define the formation and reproduction } \\
\text { of capitalism all over the world [23] }\end{array}$ & $\begin{array}{l}\text { New York, London, Tokyo } \\
\text { and others }\end{array}$ \\
\hline $\begin{array}{c}\text { Allen J. Scott } \\
\text { «egions and the } \\
\text { World Eco- } \\
\text { nomy», } 1997\end{array}$ & $\begin{array}{l}\text { Uses the notion of "global city region». Its definition is } \\
\text { not limited to administrative boundaries. The center relies } \\
\text { on the entire city region, which is drawn into the pro- } \\
\text { cesses of globalization and serves as a spatial platform for } \\
\text { them [15] }\end{array}$ & $\begin{array}{l}\text { Cities with a population of } \\
\text { more than } 1 \text { million people }\end{array}$ \\
\hline $\begin{array}{l}\text { P. Marcuse, } \\
\text { R. Van Kempen } \\
\text { «Globalizing Cit- } \\
\text { ies: A New Spa- } \\
\text { tial Order?» 2000 }\end{array}$ & $\begin{array}{l}\text { Globalizing cities is a city in the process of globalization. } \\
\text { The world city is understood not as a normative concept, } \\
\text { not as a status that can be achieved, but as a direction of } \\
\text { development that cities around the world want in the pro- } \\
\text { cess of globalization [15] }\end{array}$ & $\begin{array}{l}\text { New York, London, Tokyo } \\
\text { and others }\end{array}$ \\
\hline $\begin{array}{c}\text { E. Isin } \\
\text { «Being Political: } \\
\text { Genealogies of } \\
\text { Citizenship», } \\
2002\end{array}$ & $\begin{array}{l}\text { Cosmopolis - a city of world significance. Emphasizes } \\
\text { the continuity of urban development, starting with the } \\
\text { ancient polis. The development of the city receives a spe- } \\
\text { cial economic direction in the conditions of globalization } \\
\text { [15] }\end{array}$ & Cities of the future \\
\hline $\begin{array}{l}\text { B. L. Glazychev } \\
\text { «Urbanistics», } \\
2008\end{array}$ & $\begin{array}{l}\text { Global city is a strategic space in which global processes } \\
\text { take place on the territory of the state, and global dynam- } \\
\text { ics overcomes state institutional measures. In this sense, } \\
\text { the global city model rejects the notion that global and } \\
\text { national economies are mutually exclusive [2] }\end{array}$ & $\begin{array}{l}\text { New York, London, Tokyo } \\
\text { and others }\end{array}$ \\
\hline $\begin{array}{l}\text { I. M. Voronin } \\
\text { «Formation of } \\
\text { global cities as a }\end{array}$ & $\begin{array}{l}\text { Global cities are the largest global centers, places of con- } \\
\text { centration of the most important economic, financial, and } \\
\text { political functions occupying strategic positions in the }\end{array}$ & $\begin{array}{l}\text { New York, London, Tokyo } \\
\text { and others }\end{array}$ \\
\hline
\end{tabular}




\begin{tabular}{|c|c|c|}
\hline $\begin{array}{l}\text { result of the imp- } \\
\text { act of glo- } \\
\text { balization and } \\
\text { informatization } \\
\text { processes on the } \\
\text { resettlement sys- } \\
\text { tem», } 2009\end{array}$ & $\begin{array}{l}\text { world economy. They tend to concentrate team functions } \\
\text { and high-level service companies focused on global mar- } \\
\text { kets [1] }\end{array}$ & \\
\hline $\begin{array}{l}\text { N. A. Sluka } \\
\text { «Evolution of the } \\
\text { Concept of World } \\
\text { Cities», 2005; } \\
\text { «The Global } \\
\text { City: Theory and } \\
\text { Reality», 2007; } \\
\text { «Global urban } \\
\text { regions as the } \\
\text { main form of the } \\
\text { territorial org- } \\
\text { anization of the } \\
\text { world system», } \\
2011\end{array}$ & $\begin{array}{l}\text { Global cities are agglomerations with enormous financial, } \\
\text { managerial, information and political functions; the lar- } \\
\text { gest aircrafts of the world; locations of headquarters of } \\
\text { major transnational companies, transnational banks and } \\
\text { specialized business services; centers of innovation gen- } \\
\text { eration; key players in virtually all world markets; are } \\
\text { formed as the most important nodes of world economic } \\
\text { relations and international relations }[3 ; 14 ; 15]\end{array}$ & $\begin{array}{l}\text { The overwhelming maj- } \\
\text { ority of capitals of dev- } \\
\text { eloped countries of the } \\
\text { world }\end{array}$ \\
\hline $\begin{array}{c}\text { S. McQuire } \\
\text { «The Media City: } \\
\text { Media, Arc- } \\
\text { hitecture and } \\
\text { Urban Space», } \\
2014\end{array}$ & $\begin{array}{l}\text { The global city becomes a media city: digital networks of } \\
\text { information space are beginning to form the social profile } \\
\text { of the inhabitant of the global city, his views, and digital } \\
\text { technologies «format» the idea of time and space, thereby } \\
\text { developing competitive strategies of the global city amo- } \\
\text { ng other cities. The socio-economic competitive gap is } \\
\text { thus created within the global city through the maximum } \\
\text { use of media technologies in the information environment } \\
\text { [8] }\end{array}$ & $\begin{array}{l}\text { New York, London, Tokyo } \\
\text { and others }\end{array}$ \\
\hline $\begin{array}{c}\text { «Microturbanism. } \\
\text { The city is in det- } \\
\text { ail»», } 2014\end{array}$ & $\begin{array}{l}\text { An interactive city is a city that goes beyond its physical } \\
\text { boundaries through network quality [10] }\end{array}$ & $\begin{array}{l}\text { New York, London, Tokyo } \\
\text { and others }\end{array}$ \\
\hline $\begin{array}{l}\text { O. Y. Matveeva } \\
\text { «Global cities - } \\
\text { cities that change } \\
\text { the socio-cultural } \\
\text { space», } 2015\end{array}$ & $\begin{array}{l}\text { The global city accumulates all socio-cultural processes } \\
\text { and determines the dynamics of socio-cultural dev- } \\
\text { elopment, the change of world space in the centripetal } \\
\text { direction, as well as the nature of this dynamics, which } \\
\text { increases from the periphery to the center. This kind of } \\
\text { change allows us to consolidate the notion of rappers in } \\
\text { world cities. Rapper is a landmark that sets the direction } \\
\text { of general development that changes the dynamics of the } \\
\text { socio-cultural space [9] }\end{array}$ & $\begin{array}{l}\text { New York, London, Tokyo } \\
\text { and others }\end{array}$ \\
\hline $\begin{array}{l}\text { V. A. Dergachev } \\
\text { (Institute of Geo- } \\
\text { politics of Pro- } \\
\text { fessor Dergachev: } \\
\text { Network project) }\end{array}$ & $\begin{array}{l}\text { World (open) cities - the largest historical materialized } \\
\text { poles in the multidimensional space of the Earth's space, } \\
\text { the formation of which occurs when this place in a par- } \\
\text { ticular social time is manifested in the intersection of } \\
\text { material, cultural and information flows. The world's city } \\
\text { does not belong to the people, but a mass that denies tra- } \\
\text { ditions and culture. A resident of a world city - a man } \\
\text { torn from tradition. World cities (interpolises, int- } \\
\text { ernational metropolitan centers) act as leaders of a «glo- } \\
\text { bal» economy and society, and thus more and more dis- } \\
\text { tant from the internal periphery. The world city is the cen- } \\
\text { ter of inter-civilization dialogue, which has concentrated } \\
\text { enormous material and spiritual wealth, including culture } \\
\text { and science [6] }\end{array}$ & $\begin{array}{l}\text { New York, London, Paris, } \\
\text { Hong Kong, Singapore, } \\
\text { Istanbul, Moscow and oth- } \\
\text { ers. } \\
\text { Strategic capitals - Was- } \\
\text { hington, in the future - } \\
\text { Beijing. } \\
\text { World financial capitals - } \\
\text { New York, Frankfurt am } \\
\text { Main, Tokyo, Shanghai, } \\
\text { Moscow }\end{array}$ \\
\hline
\end{tabular}


presence of the dominant one-, two-way links supporting the system [12].

Thus, several approaches to identifying the phenomenon of a world city based on different principles but closed within the framework of invariants combination of three main parameters of the international influence of the city: «space», «time» and «scale of force» [12]:

1) geoeconomic approach: the emergence and development of world cities is directly related to the growth of their economic power. Therefore, world cities act as centers of the world economy and finance, which concentrate financial and industrial and technical power and determine the main trends of business activity within the various spatiotemporal stages of world economic development; manage, manipulate, dictate and define the formation and reproduction of capitalism all over the world; are important global manufacturing centers, key players in virtually all world markets, command and control centers of the global economic system, locations of headquarters of major transnational companies, transnational banks, specialized business services, etc.;

2) socio-cultural approach: world cities accumulate in themselves all socio-cultural processes and determine the dynamics of sociocultural development of world society; act as the largest religious centers, forming for centuries the consciousness and culture of the vast human masses (Jerusalem, Mecca, etc.); develop as creative cities, the obligatory condition of functioning of which is the presence of the formed creative class and creative economy [17]; have an overproportional share of world culture, arts, entertainment, tourism, etc.;

3) geopolitical approach: world cities are endowed with enormous political functions; act as locations of headquarters of various international intergovernmental and non-governmental organizations; become leaders in the world political system along with the states; are the centers of political power of the national and world level, cities with an overproportional share of world politics, etc.;

4) historical-geographical approach: many centers of the Ancient World are included in the world's cities, empires and metropolises, whose sphere of influence covered enormous space, inhabited by numerous peoples (for example, Babylon, Rome, etc.);

5) geodemographic approach: world cities are concentration of large population; have enormous demographic potential; act as global agglomerations, forming a solid network of resettlement on the Earth's surface; are part of the supporting frame of the urban settlement of the planet; are global centers for the exchange of human resources;

6) information and communication approach: world cities are endowed with enormous information functions; they play a crucial role in the development of the information society, creating the necessary network of decision-making variations at the highest level in different fields. They are key elements of the global system of information flows, go beyond their physical boundaries through network quality; are the centers of powerful transport streams and communications, etc.;

7) service approach: world cities specialize in professional business services, including accounting, auditing, legal services, advertising business, consulting, marketing, FIRE (finance, insurance, real estate), etc.;

8) innovative approach: world cities are developing as the largest educational and research centers, places for generating innovations, key elements of the global innovation system, the main players in the global market for the latest technological achievements, and so on.

Certainly, it is not expedient to confine ourselves to only one approach when studying world cities. In this context, the human-geographical approach, which combines all the above-mentioned and provides the most comprehensive study of the phenomenon of world cities, looks important.

In this context, one important detail on which N. A. Sluka («Evolution of the Concept of World Cities», 2005) has first exacerbated his viewpoint: the majority of the concepts of world cities are based primarily on geoeconomic approaches. From the standpoint of geographical science, the main disadvantage of these classical works is that the main emphasis in them is directed only at a simple measurement of the characteristics of global cities, while ignoring the spatial (in fact, geographic) aspect and such an important system component as socio-economic interrelations between individual elements of city networks. Although there is an assertion that globalization can lead to a loss of meaning in the concepts of «space» and "geography», but rather we must speak of a constant re-evaluation and a change in the structure of spatial configurations in the process of intensifying transnational relationships [15].

The significance of the human-geographical approach to the study of world cities is compounded by the fact that these studies are now aimed primarily at deepening the study of the national specificity of the world cities development by individual countries. At the same time, the GaWC research network in new publications not only updates the data on new cities in the world, but also conducts detailed research of cities in their 
individual regions in order to reveal certain peculiarities of the globalization process influence on their development [13].

Conclusions. The phenomenon of world (global) cities is of considerable interest and is the subject of research for the specialists from different spheres. The author of the concept «world city» is the P. Geddes, the urbanist from Britain (1915), the concept of «global city» - professor of sociology of the University of Chicago S. Sassen (1991). In modern scientific literature there are a number of terms that describe the phenomenon of world cities, in particular, including «global city», «world center», «world financial center», «cosmopolis», «information city», «media city», «metropolis», «ecumenopolis», «global city region», «capitals of capital», «international city», «globalizing city» «megacity», «interactive city», etc. Definition of the concept of «world cities» is based on such aspects as economic development, political influence, social significance.

Several approaches to identifying the phenomenon of a world city based on different principles can be singled out: geoeconomic, geopolitical, socio-cultural, historical-geographic, geodemographic, information and communication, service, innovation. An important humangeographical approach, which combines all of the above-mentioned and provides the most comprehensive study of the phenomenon of world cities.

\section{References}

1. Воронін, I. М. Формування глобальних міст як результат впливу процесів глобалізації й інформатизації на систему розселення [Електронний ресурс] / I. М. Воронін // Ученые записки Таврического национального университета им. В. И. Вернадского. Серия : География. - 2009. - Т. 22 (61). - № 2. - С. 167-172. - Режим docmyny : \www/URL: http://sn-geography. crimea.edu/arhiv/2009/uch_22_2g/020_voron.pdf

2. Глазычев, В. Л. Урбанистика / В. Л. Глазычев. - М. : Европа, 2008. - 220 c.

3. Глобальный город: теория и реальность / Под ред. Н. А. Слуки. - М. : ООО «Аванглион», 2007. - 243 с.

4. Долгова, А. Ю. «Международный финансовый центр» и «глобальный город»: взаимосвязь понятий / А. Ю. Долгова // Вестник МГИМО-Университета. - 2017. - № 1(52). - C. 162-172.

5. Дронова, О. Л. Геоурбаністика : навч. посіб. / О. Л. Дронова. - К. : Видавничо-поліграфічний центр «Київський університет», 2014. - 419 c.

6. Інститут геополітики професора Дергачова : мережевий проект [Електронний ресурс]. - Режим доступу : http://dergachev.ru/latest-geopolitics/19.html\#.WmV9RrgpqZk

7. Лаппо, Г. М. Города на пути в будущзее / Г. М. Лаппо. - М. : Мысль, 1987. - 257 с.

8. Маккуайр, С. Медийный город: медиа, архитектура и городское пространство / С. Маккуайр. - М.: StrelkaPress, 2014. - 300 c.

9. Матвеева, О.Ю. Глобальные города - города, меняющчие социильно-культурное пространство / О. Ю. Матвеева // Вестник науки Сибири. - 2015. - № 1(16). - С. 93-97.

10. Микроурбанизм. Город в деталях. - М. : Новое литературное обозрение, 2014. - 352 с.

11. Подлепіна, П. О. Глобальні міста в міжнародному туризмі / П. О. Подлепіна, В. М. Сабадир // Вісник Харківського національного університету імені В. Н. Каразіна. Серія «Міжнародні відносини. Економіка. Країнознавство. Туризм». - 2017. - Вип. 6. - С. 198-205.

12.Понятие мировых городов. Критерии мирового города [Електроний ресурс]. - Режим доступу: http://www.geograf-stud.ru/shpargalki-na-ekzamen-po-geografii/41-otvety-na-voprosy-po-geourbanistike/840ponjatie-mirovyh-gorodov-kriterii-mirovogo-goroda.html

13. Руденко, Л. Г. Класифікація міжнародних функиій міст та їх прояв в Украӥні / Л. Г. Руденко, І. Г. Савчук // Украӥнський географічний журнал. - 2014. - № 438. - С. 38-45.

14. Слука, Н. А. География городов / Н. А. Слука // Эксперт. - 2008. - № 15 (604). - С. 68-74.

15. Слука, Н. А. Эволюциия концепции «мировых городов» / Н. А. Слука // Региональные исследования. - 2005. № 1. - C. 11-29.

16. Суптело, О. С. Суспільно-географічні передумови виникнення глобальних міст / О. С. Суптело // Другі Сумські наукові географічні читання : зб. матеріалів Всеукр. наук. конф. (м. Суми, 10-12 листопада 2017 р.). Суми, 2017. - C. 42-45.

17. Урбаністична Украӥна: в епіцентрі просторових змін : монографія / За ред. К. Мезенщева, Я. Олійника, Н. Мезенцевої. - К. : Видавництво «Фенікс», 2017. - 438 с.

18. Чернова, Г. В. Глобальні міста та сучасні тендениії їх розвитку [Електроний ресурс] / Г. В. Чернова, Ю. В. Касянчук. - Режим достуny : http://www.rusnauka.com/17_PMN_2014/Geographia/9_172066.doc.htm

19. Beaverstock, J. V. A Roster of World Cities / J. V. Beaverstock, P. G. Taylor, R. G. Smith // Cities. - 1999. - № 16. Vol. 6. - P. 445-458.

20. Berube, A. Global Cities, Present and Future: 2014 Global Cities Index and Emerging Cities Outlook [Eлекmpoнний ресурс] / A. Berube, D. Frison // ATKearney, 2014. - Режим достуny: http://www.atkearney.com/researchstudies/global-cities-index/fullreport

21. Cassis, Y. Capitals of Capital: The Rise and Fall of International Financial Centres 1780-2009 / Y. Cassis . - Cambridge University Press, 2010. - 393 p. 
22. Castells, M. The Informational City: Information Technology, Economic Restructuring, and the Urban Regional Process / M. Castells. - Oxford, UK, Cambridge, MA: Blackwell, 1989.

23. Clark, D. Urban World. Global City / D. Clark. - New York, 2003. - 156 p.

24. Ecumenopolis: Tomorrow's City / C. Doxiadis // Britannica Book of the year. -1968.

25. Friedmann, J. The World City Hypothesis / J. Friedmann // Development and Change. - 1986. - № 4. - P. 12-50.

26. Globalization and World Cities [Електронний pecypc]. - Режим доступу: http://www.lboro.ac.uk/ gawc/courol.html

27. Geddes, $P$. Cities in evolution an introduction to the town planning movement and to the study of civics / P. Geddes. - London : Williams \& Norgate, 1915. - 409 p.

28. Hall, P. World Cities / P. Hall. - New York: McGraw-Hill, 1966. - 256 p.

29. Jao, Y. Hong Kong as an International Financial Centre, Evolution, Prospects and Policies / Y. Jao. - Hong Kong City: University of Hong Kong Press, 1997. - 170 p.

30. Reed, H. Financial centre hegemony, interest rates and the global political economy / H. Reed // International Banking and Financial Centres. - London, 1989. - P. 247-268.

31. Sassen, S. The Global City: Introducing a Concept / S. Sassen // The Brown Journal of World Affairs. - Winter/Spring. - 2005. - Vol. XI. - Issue 2. - P. 27-43.

32. Thrift, N. The Geography of International Economic Disorder / N. Thrift // A World in Crisis? Geographical Perspectives. - Oxford, 1989. - P. 16-78.

33. Tschoegl, A. E. International Banking Centers, Geography, and Foreign Banks / A. E. Tschoegl // Financial Markets, Institutions and Instruments. - 2000. - № 9. -Iss. 1. - P. 1-32.

34. The World's Cities in 2016: Data Booklet [Електронний ресурс]. - Режим доступy: http://www.un.org /en/development/desa/population/publications/pdf/urbanization/the_worlds_cities_in_2016_data_booklet.pdf

35. Taylor, P. World City Network: A Global Urban Analysis / P. Taylor. - Routledge, 2004.

УДК 504.53.052

*О. В. Дєдов, к. с.-г. н., доиент,

**В. І. Пасічняк, директор,

**М. І. Нагрибецький, начальник дослідної лабораторії,

*Вінницький державний педагогічний університет імені М. Коцююбнського, **Вінницька філія державної установи “Інститут охорони трунтів Украӥни”

\title{
ГРУНТИ В УМОВАХ КЛІМАТИЧНИХ ЗМІН: АДАПТАЦІЯ, РЕАДАПТАЦІЯ, ПРЕАДАПТАЦІЯ?
}

\begin{abstract}
Наведено дані про прогнозоване потепління клімату в Украӥні та його негативний вплив на трунти. Проаналізовано розроблені стратегії адаптачії сільського господарства до кліматичних змін. Обгрунтовано злободенність покращення гумусованості трунтів як запоруки підвищення їх стійкості до посилення екстремальності клімату й забезпечення продуктивного використання тепер і в майбутньому. Доведено значущість застосування для иьього замість стратегії адаптації (повільного пристосування до змін клімату) попереджувальної тактики - ре- (відновлення втрачених ними важливих складових і властивостей) та преадаптачії (подальшим їх покращенням), необхідність припинення практики трунтовиснажливого землеробства зі збільшенням у сівозмінах посівів кукурудзи, соняшника, ріпаку (на Поділлі за період 2010-2015 рр. відповідно на 5,6, 1,2 та 0,4 \% з часткою їх у них 16,9, 6,2 і 5,8\% при рекомендованих нормах для лісостепу 20, 5-9 та 3-5 \%) $i$ зменшенні трунтополіпшуючих трав (відповідно з 7,9 до 6,4\% при нормі більше $10 \%$ ) та впровадження трунтовідновних зерно-трав'яних сівозмін.
\end{abstract}

Ключові слова: потепління клімату, адаптачія, реадаптачія, преадаптачія, гумус, сівозміни, трави.

А. В. Дедов, В. И. Пасичняк, М. И. НагрибецкИй. ПОЧВЫ В УСЛОВИЯХ КЛИМАТИЧЕСКИХ ИЗМЕНЕНИЙ: АДАПТАЦИЯ, РЕАДАПТАЦИЯ, ПРЕАДАПТАЦИЯ? Приведены данные о прогнозированном потеплении климата в Украине и его неблагопрятном влиянии на агроландмафты и почвы. Проанализированы разработанные стратегии адаптации сельского хозяйства к изменениям климата. Обосновано злободневность улучшения гумусированности почв - основы повышения их устойчивости к усилению экстремальности климата и обеспечения продуктивного использования в новых условиях среды. Доказана важность использования для этого вместо стратегии адаптации (медленного приспособления почв $к$ изменениям климата) упреждающей тактики - ре- (восстановление потерянных ими важных полезных качеств) с последующей преадаптацией (их улучшением), необходимость прекращения почвоистощающего земледелия с увеличением в севооборотах посевов кукурузы, подсолнечника, рапса (на Подолье за период 2010-2015 г2. соответственно на 5,6, 1,2 и 0,4 \% с долей их у структуре посевов 16,9, 6,2 и 5,8 \% при нормах для лесостепи 20, 5-9 и 3-5 \%) и уменьшении почвоулучшаюших трав (соответственно с 7,9 до 6,4 \% при норме более $10 \%$ и использования почвовосстанавливающих зерно-травяных севооборотов.

Ключевые слова: потепление климата, адаптация, реадаптация, преадаптация, гумус, севооборот, травы.

Актуальність. Планетарне підвищення температури повітря зі збільшенням частоти і сили екстремальних кліматичних явищ негативно вплинуло на досить залежні від клімату агроландшафти та важливі їх компоненти - грунти (основний засіб сільськогосподарського виробництва). Забезпечення відновного їх функціонування в сучасних складних екологічних умовах та погіршенні кліматичних в майбутньому на фоні зростання господарських, рекреаційних, естетичних (C) Дєдов О. В., Пасічняк В. І., Нагрибецький М. I., 2017 https://doi.org/10.26565/2410-7360-2017-47-12 